\title{
Predicting Customer Satisfaction and Customer-Company Identification in Enhancing Halal Restaurant Loyalty: Service Encounters Perspective
}

\author{
Ali Mursid* \\ Assistant Professor in Department of Management, \\ Bank BPD Jateng School of Economics and Business, Semarang, Central Java, Indonesia. \\ Email: ali.mursyid14@gmail.com
}

\begin{abstract}
This study proposes a theoretical framework of halal service encounters includes physical environments, serviceemployee to customer interaction, and customer-to-customer interaction to predict customer satisfaction and customercompany identification. Hence, it verifies the effect of customer satisfaction and customer-company identification on hala restaurant loyalty. The result of the survey from 520 favorite halal restaurants customers in Semarang City Indonesia, shows that all the elements of halal service encounters include physical environments, service employee-to-customer interaction, and customer-to-customer interaction positively affect customer satisfaction. Hence, physical environments cannot successfully predict customer-company identification, while service employeeto-customer and customer-to-customer interaction positively affect customer-company identification. Two of the elements of halal service encounters namely service employee-to-customer interaction and customer-to-customer interaction have become good predictors of both customer satisfaction and customercompany identification. Finally, both customer satisfaction and customer-company identification affect halal restaurant loyalty. This study discusses the results, offer managerial implication, and state the limitation of this study as well as recommends for further study.
\end{abstract}

Keywords: service encounters, customer satisfaction, customercompany identification, halal restaurant loyalty

\section{INTRODUCTION}

Indonesia has a very high potency for developing culinary business with approximately total consumption of IDR 844.35 trillion. However, the opportunity of building the restaurants business is also relevant with high competition in this sector. It shows that many new restaurants appears and many others go in bankruptcy (Al-Hafidz, 2019). This phenomenon attracts this study to explore customer behavior particularly customer satisfaction and customer-company identification in achieving customer loyalty towards halal favorite restaurants from the perspective of service encounters.

Customer satisfaction and customer-company identification has acknowledged as the important factors in enhancing customer loyalty (Grissemann \& Stokburger-Sauer, 2012). Moreover, the objective of relationship marketing in each industry is to achieve a high level of customer satisfaction (Clark, Peck, Payne, \& Christopher, 1995). On the other side, customer-company identification has been proposed as the critical factor in enhancing customer loyalty (Bhattacharya \& Sen, 2003). Customer company identification is believed to build customer loyalty in the long term of airline service (Haumann, Quaiser, Wieseke, \& Rese, 2014).

Although previous studies have recognized both of the two constructs; only a few numbers of previous scholars have explored the antecedents of both customer satisfaction and customer-company identification (see (Martínez \& Del Bosque, 2013; Su, Swanson, Chinchanachokchai, Hsu, \& Chen, 2016; Yang, Chen, \& Huang, 2017). This study attempts to fill this gap by exploring the antecedents of both customer satisfaction and customer-company identification in a single framework from the perspective of service encounters that rarely covered by extant studies. In addition, this study fills the gap by adopting service encounters that previous literatures rarely include in evaluating the antecedents of customer company identification (see (Ahearne, Bhattacharya, \& Gruen, 2005; Ahn, Shamim, \& Park, 2020; Fatma, Khan, \& Rahman, 2018; Kuenzel \& Halliday, 2008; Martínez \& Del Bosque, 2013; Su et al., 2016). Finally, this study investigates of customer satisfaction and customer-company identification in enhancing customer loyalty that still becoming a trending topic until recently ((Popp \& Woratschek, 2017; Yang et al., 2017). This study would like to articulate that the two constructs has become the key points of influencing customer loyalty in halal favorite restaurants.

\section{LITERATURE REVIEW AND HYPOTHESIS DEVELOPMENT}

\section{A. The elements of service encounters and customer satisfaction}

In restaurant context, several authors have proved the direct relationship between physical environment and customer satisfaction. Lin and Mattila (2010) examined customer interaction of servicescape and customer satisfaction in the restaurant setting. The result shows that servicescape positively affects customer satisfaction. The serviscape in quick restaurant has also been reported as the determinant factor in enhancing customer satisfaction (Ryu and Han, 2010). A recent study conducted by Nunkoo et al (2020) reported that security, safety and room quality of the hotel significantly impacts customer 
satisfaction. Therefore, this study proposes the following hypothesis.

H1: Physical environment significantly affects customer satisfaction.

The quality of interaction between service employee and customer has acknowledged as the key factor in predicting customer satisfaction (Bitner, Booms \& Mohr, 1994). Alhelalat, Habiballah, and Twaissi (2017) reported that service employee behavior in restaurants both personal and functional successfully explain customer satisfaction. Wu and Liang (2009) have informed that service employee-to-customer communication has a direct effect on customer satisfaction in hotel restaurants. Likewise, Lin and Matila (2010) also found that service encounter or interaction between service employee and customer affect directly on customer satisfaction in restaurants setting. Therefore, this study offers the following hypothesis.

$\mathrm{H} 2$ : Service employee-to-customer interaction positively and significantly affects customer satisfaction.

A previous study adopting customer-to-customer communication described the construct more details into six incidents namely protocol, social, violent, grungy, malcontent, crude and inconsiderate. It is identified that protocol and sociable evidence impact positively and significantly on fellow customer evaluation and conversely, malcontent negatively impact on customer satisfaction (Wu, 2007). More recent study reported that customer interaction with other customer significantly affects customer satisfaction and social wellbeing (Atinay et al., 2019). Therefore, this study presents the following hypothesis.

H3: Customer-to-customer interaction positively and significantly affects customer satisfaction.

The thought of identifying customer-company identification from physical environments aspects based on Underwood, Bond, and Baer (2001) that proposed conceptual of physical environment consist of group experience, history/tradition, physical facility, and ritual in the sports industry. This concept argued that physical facility is a core of brand association. It was illustrated several companies such as Oskosh B'Gosh, Disney, Nike, Hallmark, and McDonald's have a strong brand association in the eyes of consumers. In addition, the architecture design of arena in NBA's Indiana is an example of identity conveyance. Focusing on the facility this study proposed that facility associated with brand enhance customer brand identification, therefore this study proposed the following hypothesis.

H4: Physical environments significantly affects customercompany identification.

This study attempts to relate this relationship by considering several indications, for instance, Konu (2015) employed the ethnographic approach to depict customer involvement by examining new service development based on the active interaction between customer and service employee under a variety of conditions. The results reveal consumers' contributions to the service model and tourism package. Similarly, Ahn and Rho (2016) reported that relationship value and communication significantly affect customer participation intentions during service encounters. Focusing on customercompany identification, Marin and Maya (2013) found that personal connection with salesperson impact on customercompany identification. Based on the above direction this study proposes the following hypothesis.

H5: Service-employee-to customer interaction significantly affects customer-company identification.

Belk (1975) showed that other customers have become a part of the social environment that potentially affect customer perception with their interaction and word of mouth. Georgi and Mink (2013) recommended for the company to perform a good concept and management of customer-to-customer interaction since sharing between the customer experiences is crucial in innovative business model. Customer-to-customer interaction is not so far different to service employee-to-customer interaction that represents the interaction about business. The empirical study from Karaosmanoglu and Bas (2011) found that other customer affects significantly on customer-company identification and hence impact on customer outcome, therefore the following hypothesis is proposed.

H6: Customer-to-customer interaction positively and significantly affects customer-company identification.

\section{B. Customer satisfaction, customer-company identification and halal restaurant loyalty.}

Previous studies have been identified the direct effect of customer satisfaction on customer loyalty in various settings. Paswan, Spears, and Ganesh (2007) suggested that customers who received a good service as their preference possess a higher satisfaction and impact on a greater loyalty to the brand. Similarly, Walsh, Evanschitzky, and Wunderlich (2007) reported that customer satisfaction has a positive effect on customer loyalty. Kim, Vogt, and Knutson (2015) concluded that customer satisfaction is the key factor that determines customer loyalty both cognitive and affective loyalty. A prior study reported the direct influence of customer satisfaction on customer loyalty (Wolter, Bock, Smith, and Cronin, Jr. 2017), and a recent study focused on Muslim travelers reported that tourist satisfaction enhance customer loyalty (Fajriati et al, 2020). Therefore, the following hypothesis is offered. therefore, this study proposed the following hypothesis. H7: Customer satisfaction positively and significantly affects halal restaurant loyalty.

Several previous authors also prove that customer company identification directly affects customer loyalty. Kuenzel and Halliday (2008) investigated brand identification to predict word of mouth and brand repurchase informed that the effect of brand identification on customer word of mouth and brand repurchase is significant. Stokburger-Sauer, Ratneshwar, and Sen (2012) found that customer brand identification directly affects brand loyalty. Martinez and Bosque (2013) reported that customer company identification has a direct effect on customer loyalty. Likewise, Haumann, Quaiser, Wieseke, \& Rese (2014) 
in their comparison study informed that customer company identification affects customer loyalty. In more detail, customer company identification described into cognitive and affective aspect. This study shows that cognitive and affective customer company identification positively affects attitudinal loyalty (Wolter and Cronin, 2016). A previous study conducted by Yang, Chen \& Huang (2017) demonstrated that customer company identification positively impacts on customer loyalty. Hence, Ahn, Shamim, and Park (2020) found that customer identification significantly influences customer loyalty in the context of cruise in industry, therefore, this study purposes the following hypothesis.

H8: Customer-company identification positively and significantly affects halal restaurant loyalty.

\section{Research framework}

This study explores customer satisfaction and customercompany identification in enhancing halal restaurant loyalty from the perspective of service encounters include physical environments, service employee-to-customer interaction, and customer-to-customer interaction. Finally, it investigates the influence of customer satisfaction and customer-company identification on halal restaurant loyalty. Figure 1 depicts the theoretical framework.

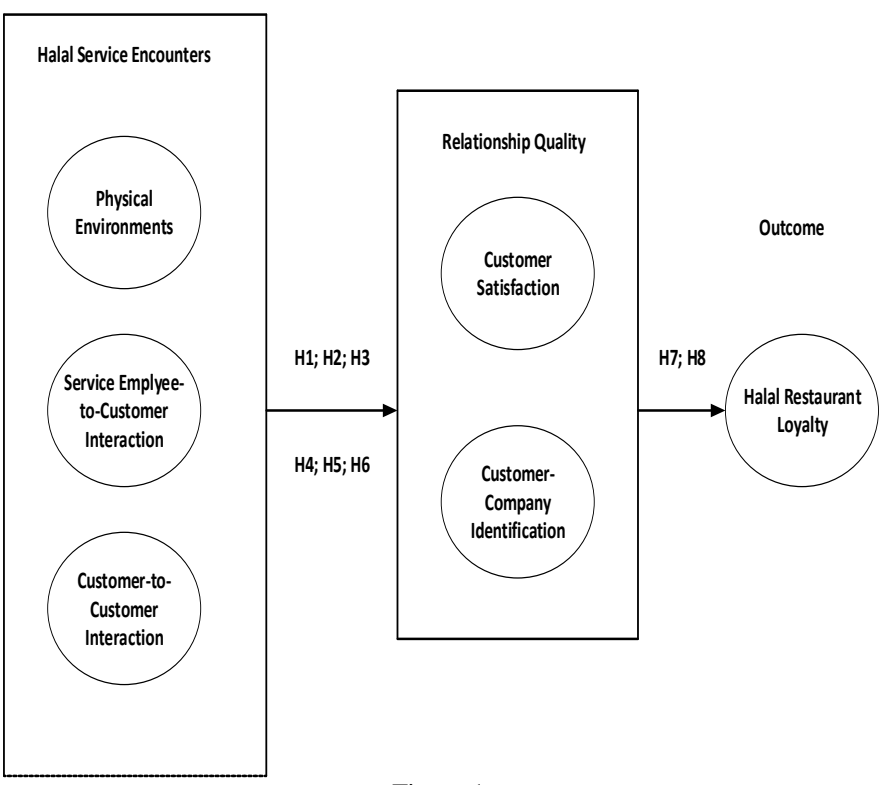

Figure 1.

A proposed model of service encounters and halal restaurant loyalty.

\section{METHODOLOGY}

\section{A. Sample and data collection}

This study focused on the customers of ten favorite halal restaurants in Semarang, Indonesia as recommended by trip advisor. The survey employs a seven-point scale to identify the response of respondents based on the questionnaires from strongly disagree (1) to strongly agree (7). Furthermore, this framework, this describes socio-demographics profile include age, gender, monthly income, education level, and marital status. This study also conducted pilot test to 50 respondents of customers in some favorite halal restaurants to check the Cronbach alpha, KMO-MSA and revised the questionnaires based on the respondents' feedback. All of each construct in this framework achieve Cronbach alpha exceeds .70, and KMOMSA above .60 and almost all of the statements in the questionnaires are well understood by the respondents. After improving minor revision of the questionnaires, then this study conducts the real survey. Totally, 750 questionnaires were distributed to the customers using purposive sampling methods and 570 response returned or the response rate is $76 \%$. This study selected 520 of the fix questionnaires after screening the data and then continue to the process of analysis.

\section{B. Measurement scale}

This survey used the measurement scale of each construct based on the previous studies that are established to use in the research. The measurement scale of halal service encounters consists of physical environments, service employee-tocustomer interaction, and customer-to-customer interaction then modified from suitable previous researchers. Service employee-to-customer interaction is adapted from Anderson and Weitz (1992) and Price, Arnould, and Deibler (1995) consists of six items. Furthermore, physical environments revealed from Wakefield and Baker (1998) includes four items, while customer-to-customer interaction is extracted from Gruen, Osmonbekov, and Czaplewski (2007) totally three items. The items scale of customer satisfaction modified from Gremler and Gwinner (2000) involved three items. Hence, customer company identification scales adapted from Mael and Ashforth (1992) consist of five items. Finally, the construct of halal restaurant loyalty is modified from Zeithaml, Berry, and Parasuraman (1996) include four items.

\section{ANALYSIS AND RESULTS}

\section{A. Socio-demographics profile of respondents}

The results of the analysis focused on socio-demographics respondents demonstrated that male customers (59.6\%) are higher than female-customers $(40.4 \%)$. Furthermore, the age of the participants in this study is dominated by 20-27 years old $(80.6 \%)$. Majority of the respondents are single which achieved $81.9 \%$ and spouse participants are only $15.8 \%$. The highest education background of this respondents are master students $(69.6 \%)$ followed by undergraduate education level $(25.2 \%)$, and the remains respondents are doctoral degree (3.8\%). Their household income of the respondent's majority is < IDR 5.000.000 (86.5\%) and the second highest income are between IDR 5.000.000 and < IDR 7.500.000 (12.3\%). Finally, the visiting frequency of the customer coming to visit the favorite halal restaurants are 4-5 times (43.3\%), and followed by more than 5 times (39.6\%). 


\section{B. Confirmatory factor analysis (CFA) and structural equation modelling}

The analysis data is employed two-steps approach include confirmatory factor analysis (CFA) and structural equation modelling (SEM). The analysis of CFA is to examine the discriminant validity and convergent validity of the measurement model; hence, structural equation modeling is related to hypotheses testing. All of each construct in this framework achieved the value of Cronbach alpha between .856 and .949 higher than .070 as recommended by (Nunnally, 1994).

\section{Measurement Model}

The result of confirmatory factor analysis (CFA) demonstrated that all the proposed constructs exhibited significant factor loadings $(\mathrm{p}<.01)$ and the statistics analysis for the measurement model shows a good model fit. In addition, the construct of reliability (CR) of each scale approach exceeds .80, indicating adequate fit (Nunnally \& Bernstein, 1994). Including those from physical environments (.868), service employee-tocustomer interaction (.890), customer-to-customer interaction (.946), customer trust (.919), customer satisfaction (.864), customer-company identification (.941), and customer loyalty (.841). Concerning the validity test, the result of CFA analysis demonstrated the average variance estimate (AVE) between .569 and .800 indicated that the construct in the proposed model is satisfied (Anderson \& Gerbing, 1988).

The inter-construct correlation of the diagonal of the matrix and square root of average variance extracted (AVE) on the diagonal of the matrix, comparing the square roots of AVEs with their associated pair of correlations, the correlation coefficients among latent variables were less than the square roots of AVEs, which indicates adequate discriminant validity. The analysis of measurement model shows an adequate model fit with $\chi^{2}=614.951, \mathrm{df}=270\left(\chi^{2} / \mathrm{df}=2.278\right)$; RMR $=.045$, RMSEA $=.050$, NFI $=.941$, RFI $=.929$, IFI $=.966$, TLI $=$ $.959, \mathrm{CFI}=.966, \mathrm{AIC}=776.951$, and $\mathrm{BIC}=1121.511(\mathrm{Hu} \&$ Bentler, 1999).

\section{Structural Model}

The result of structural model analysis shows a good model fit with $\chi^{2}=701.745, \mathrm{df}=275\left(\chi^{2} / \mathrm{df}=2.552\right) ; \mathrm{RMR}=.075$, RMSEA $=.055, \mathrm{NFI}=.933, \mathrm{RFI}=.921, \mathrm{IFI}=.958, \mathrm{TLI}=$ $.950, \mathrm{CFI}=.958, \mathrm{AIC}=853.745$, and $\mathrm{BIC}=1177.036(\mathrm{Hu}$ and Bentler, 1999).

The result of the hypotheses testing from structural model shows that all the elements of halal service encounters namely physical environments (H1), service employee-to-customer interaction $(\mathrm{H} 2)$, and customer-to-customer interaction significantly affect customer satisfaction (H3). Moreover, the results of the relationship between halal service encounters and customer-company identification, it reported that physical environments insignificantly affect customer-company identification (H4), while service employee-to-customer interaction (H5) and customer-to-customer interaction (H6) significantly impact customer-company identification. Concerning halal service encounters to predict customer trust, the results show that physical environments $(\mathrm{H} 7)$ and service employee-to-customer interaction (H8) significantly impacts customer trust, conversely customer-to-customer interaction (H9) cannot successfully affects customer trust. In turn, customer trust effectively affects customer satisfaction (H10) and customer-company identification (H11). Finally, customer satisfaction (H12) and customer-company identification (H13) significantly affect halal restaurant loyalty. Any details of the hypotheses results displayed in the following table.

TABLE 1 DISPLAYED ANY DETAILS OF THE HYPOTHESES

\begin{tabular}{|c|c|c|c|c|c|}
\hline \multicolumn{6}{|c|}{ RESULTS. } \\
\hline & pothesis & Estimate & S.E. & C.R & Result \\
\hline H1 & $\mathrm{PE} \rightarrow \mathrm{CS}$ & $.147 * *$ & .052 & 2.811 & Supported \\
\hline $\mathrm{H} 2$ & $\mathrm{~S} 2 \mathrm{C} \rightarrow \mathrm{CS}$ & $.120 * *$ & .047 & 2.555 & Supported \\
\hline H3 & $\mathrm{C} 2 \mathrm{C} \rightarrow \mathrm{CS}$ & $.118 * * *$ & .028 & 4.227 & Supported \\
\hline $\mathrm{H} 4$ & $\mathrm{PE} \rightarrow \mathrm{CCI}$ & -.119 & .090 & -1.317 & $\begin{array}{c}\text { Not } \\
\text { supported }\end{array}$ \\
\hline H5 & $\begin{array}{l}\mathrm{S} 2 \mathrm{C} \rightarrow \\
\mathrm{CCI}\end{array}$ & $.243 * *$ & .082 & 2.955 & Supported \\
\hline H6 & $\begin{array}{l}\mathrm{C} 2 \mathrm{C} \rightarrow \\
\mathrm{CCI}\end{array}$ & $.368 * * *$ & .049 & 7.579 & Supported \\
\hline H7 & $\mathrm{CS} \rightarrow \mathrm{HL}$ & $.413 * * *$ & .052 & 7.899 & Supported \\
\hline H8 & $\mathrm{CCI} \rightarrow \mathrm{HL}$ & $.284 * * *$ & .027 & 10.574 & Supported \\
\hline
\end{tabular}

Note: $* \mathrm{p} \leq .1 * * \mathrm{p} \leq .05$ and $* * * \mathrm{p} \leq .001 ; \mathrm{PE}=$ Physical Environments; $\mathrm{S} 2 \mathrm{C}=$ Service Employee-to-Customer Interaction; C2C = Customer-to-Customer Interaction; CS = Customer Satisfaction; CCI = Customer-Company Identification; HL = Halal Restaurant Loyalty

\section{E. Conclusion and Discussion}

This study confirms three elements of service encounters namely service employee-to-customer interaction, customer-tocustomer interaction as well as physical environments have become strong predictor of customer satisfaction. Concerning the relationship between the elements of service encounters and customer-company identification, this study found that service employee-to-customer interaction and customer-to-customer interaction successfully predict customer-company identification, while physical environment fail to predict customer-company identification. Both customer satisfaction and customer-company identification has become determinant factors of halal restaurant loyalty.

The significant effect of physical environments on customer satisfaction strengthen the majority of previous studies (Lin and Mattila, 2010; Ryu and Han, 2010). Moreover, the significant result of service employee-to-customer interaction on customer satisfaction is relevant to the previous finding (Alhelalat, Habiballah, and Twaissi, 2017; Wu and Liang, 2009; Lin and Matila, 2010). Similarly, the results of customer-to-customer interaction significantly affects customer satisfaction agree with prior studies (Wu, 2007; Atinay et al., 2019). It can be concluded that service encounters include three elements namely physical environment, service employee-to-customer interaction and customer-to-customer interaction are determinant factor of customer satisfaction.

Moreover, this study only answers two of the elements of service encounters include service employee-to-customer interaction and customer-to-customer interaction that successfully predict customer-company identification, while physical environments fail to predict customer-company identification. The confirmation result of service employee-to- 
customer interaction on customer-company identification relevant with the study from Hau et al. (2017) that describes individuated interaction, relational interaction, and empowered interaction impact on customer contribution. This finding supports Marin and Maya (2013) who found personal connection with salesperson impact on customer-company identification. Moreover, the result of customer-to-customer interaction significantly impacts customer-company identification prove the statement that other customers have a potential impact on customer company identification (Hansen and Deutcher, 1978) and supports a previous study conducted by Karaosmanoglu and Bas (2011) that found other customer affects significantly on customer-company identification. This study failed to predict that physical environments affects customer-company identification based on the indication from Underwood, Bond, and Baer (2001) that proposed conceptual of physical environment such as the facility associated with brand enhance customer brand identification. The potential explanation of this insignificant finding, may that the theory based of the hypothesis purposes is weak. This study only purposes the hypothesis of physical environments affects customer-company identification constructed from the indication only form Underwood et al (2001).

Finally the significant effect of customer satisfaction on halal restaurant loyalty strengthen the prior researches that customer satisfaction is an established factor to determine customer loyalty in various business settings (Paswan, Spears, and Ganesh, 2007; Walsh, Evanschitzky, and Wunderlich, 2007; Kim, Vogt, and Knutson, 2015; Wolter, Bock, Smith, and Cronin, Jr, 2017; Fajriati et al, 2020). Moreover, the finding of customer-company identification affects halal restaurant loyalty supports the majority of previous studies (see Kuenzel and Halliday, 2008; Stokburger-Sauer, Ratneshwar, and Sen, 2012; Martinez and Bosque, 2013; Haumann, Quaiser, Wieseke, \& Rese, 2014; Wolter and Cronin, 2015; Yang, Chen \& Huang, (2017); Ahn, Shamim, and Park, 2020).

\section{F. Managerial implication}

The importance of customer satisfaction and customercompany identification should be considered by the manager to manage the customer. Manager should reach the goal of serving customer more than satisfaction, but create how the customer identify with the company. The manager can implement the program to create customer identify with company by maintaining continuous communication with customer who has satisfied with the service via online and offline. Moreover, the manager should facilitate the communication between service employee and customer as well as customer with other customers, this program can be implemented by creating group of interaction with the loyal customer.

\section{G. Limitation and future research direction}

This study addresses some limitation related to the sample that only focused on the halal favorite restaurants in Semarang City, therefore, future research should broaden the sample to the respondents to the halal restaurants in all the big cities in Indonesia will be more representative. Broaden the sample of halal restaurant both in Muslim countries and non-Muslim countries interesting to be identified since it may perform different customer behavior with different culture. Other different perspectives excluded service encounters to predict both customer satisfaction and customer-company identification from customer perspective such as customers psychology or from the company such as company supports or company benevolence is also interesting to be elucidated for future studies.

\section{REFERENCES}

[1] Ahearne, M., Bhattacharya, C. B., \& Gruen, T. (2005). Antecedents and consequences of customer-company identification: Expanding the role of relationship marketing. Journal of applied psychology, 90(3), 574.

[2] Ahn, J., \& Rho, T. (2016). Influence of customer-firm relationships on customer participation in the service industry. Service Business, 10(1), 113-133.

[3] Ahn, J., Shamim, A., \& Park, J. (2020). Impacts of cruise industry corporate social responsibility reputation on customers' loyalty: Mediating role of trust and identification. International Journal of Hospitality Management, 92, 102706.

[4] Al-Hafidz, M. P. (2019). Indonesia Industry Outlook 2019, Marketeer Harus Optimistis.

[5] Alhelalat, J. A., Ma'moun, A. H., \& Twaissi, N. M. (2017). The impact of personal and functional aspects of restaurant employee service behaviour on customer satisfaction. International Journal of Hospitality Management, 66, 46-53.

[6] Altinay, L., Song, H., Madanoglu, M., \& Wang, X. L. (2019). The influence of customer-to-customer interactions on elderly consumers' satisfaction and social well-being. International Journal of Hospitality Management, 78, 223-233.

[7] Anderson, \& Weitz, B. (1992). The use of pledges to build and sustain commitment in distribution channels. Journal of Marketing Research, 29(1), 18-34.

[8] Baker, J., Parasuraman, A., Grewal, D., \& Voss, G. B. (2002). The influence of multiple store environment cues on perceived merchandise value and patronage intentions. Journal of marketing, 66(2), 120-141.

[9] Belk, R. W. (1975). Situational variables and consumer behavior. Journal of Consumer research, 2(3), 157-164.

[10] Bhattacharya, C. B., \& Sen, S. (2003). Consumer-company identification: A framework for understanding consumers' relationships with companies. Journal of marketing, 67(2), 76-88.

[11] Bitner, M. J. (1990). Evaluating service encounters: the effects of physical surroundings and employee responses. Journal of marketing, 54(2), 69-82.

[12] Bitner, M. J. (1992). Servicescapes: The impact of physical surroundings on customers and employees. Journal of marketing, 56(2), 57-71.

[13] Bitner, M. J., Booms, B. H., \& Mohr, L. A. (1994). Critical service encounters: The employee's viewpoint. Journal of marketing, 58(4), 95 106.

[14] Clark, M., Peck, H., Payne, A., \& Christopher, M. (1995). Relationship marketing: towards a new paradigm. Advances in Relationship Marketing, Kogan Page, London, 263-280.

[15] Czepiel, J. A. (1990). Service encounters and service relationships: implications for research. Journal of Business Research, 20(1), 13-21.

[16] Eichhorn, B. R. (2014). Common method variance techniques. Cleveland State University, Department of Operations \& Supply Chain Management. Cleveland, OH: SAS Institute Inc, 1-11.

[17] Fajriyati, I., Afiff, A. Z., Gayatri, G., \& Hati, S. R. H. (2020). Generic and Islamic attributes for non-Muslim majority destinations: application of the three-factor theory of customer satisfaction. Heliyon, 6(6), e04324.

[18] Fatma, M., Khan, I., \& Rahman, Z. (2018). CSR and consumer behavioral responses: the role of customer-company identification. Asia Pacific Journal of Marketing and Logistics.

[19] Georgi, D., \& Mink, M. (2013). eCCIq: The quality of electronic customer-to-customer interaction. Journal of Retailing and Consumer Services, 20(1), 11-19. 
[20] Gremler, D. D., \& Gwinner, K. P. (2000). Customer-employee rapport in service relationships. Journal of Service Research, 3(1), 82-104.

[21] Grissemann, U. S., \& Stokburger-Sauer, N. E. (2012). Customer cocreation of travel services: The role of company support and customer satisfaction with the co-creation performance. Tourism Management, 33(6), 1483-1492.

[22] Gruen, T. W., Osmonbekov, T., \& Czaplewski, A. J. (2007). Customerto-customer exchange: its MOA antecedents and its impact on value creation and loyalty. Journal of the Academy of Marketing Science, 35.

[23] Haumann, T., Quaiser, B., Wieseke, J., \& Rese, M. (2014). Footprints in the sands of time: A comparative analysis of the effectiveness of customer satisfaction and customer-company identification over time. Journal of marketing, 78(6), 78-102.

[24] Hu, L. t., \& Bentler, P. M. (1999). Cutoff criteria for fit indexes in covariance structure analysis: Conventional criteria versus new alternatives. Structural equation modeling: a multidisciplinary journal, 6(1), 1-55.

[25] Karaosmanoglu, E., Bas, A. B. E., \& Zhang, J. K. (2011). The role of other customer effect in corporate marketing its impact on corporate image an onsumer-company identification. European Journal of Marketing, 45(9/10), 1416-1445.

[26] Keng, C. J., Huang, T. L., Zheng, L. J., \& Hsu, M. K. (2007). Modeling service encounters and customer experiential value in retailing. International Journal of Service Industry Management.

[27] Kevoe-Feldman, H. (2018). The interactional work of suppressing complaints in customer service encounters. Journal of Pragmatics, 123, 102-112.

[28] Kim, M., Vogt, C. A., \& Knutson, B. J. (2015). Relationships among customer satisfaction, delight, and loyalty in the hospitality industry. Journal of Hospitality \& Tourism Research, 39(2), 170-197.

[29] Koistinen, K., \& Järvinen, R. (2016). Comparing perceived insecurity among customers and retail staff during service encounters. Journal of Retailing and Consumer Services, 31, 80-92.

[30] Konu, H. (2015). Developing a forest-based wellbeing tourism product together with customers-An ethnographic approach. Tourism Management, 49, 1-16.

[31] Kuenzel, S., \& Halliday, S. V. (2008). Investigating antecedents and consequences of brand identification. Journal of Product \& Brand Management.

[32] Larivière, B., Bowen, D., Andreassen, T. W., Kunz, W., Sirianni, N. J., Voss, C., . . . De Keyser, A. (2017). "Service Encounter 2.0": An investigation into the roles of technology, employees and customers. Journal of Business Research, 79, 238-246.

[33] Lin, I. Y., \& Mattila, A. S. (2010). Restaurant servicescape, service encounter, and perceived congruency on customers' emotions and satisfaction. Journal of hospitality marketing \& management, 19(8), 819841

[34] Mael, F., \& Ashforth, B. E. (1992). A partial test of the reformulated model of organizational identification. Journal of Organizational Behavior, 13(2), 103-123.

[35] Marin, L., \& Maya, S. R. d. (2013). The role of affiliation, attractiveness and personal connection in consumer-company identification. European Journal of Marketing, 47(3/4), 655-673.

[36] Martínez, P., \& Del Bosque, I. R. (2013). CSR and customer loyalty: The roles of trust, customer identification with the company and satisfaction. International Journal of Hospitality Management, 35, 89-99.

[37] Nunnally, J. C. (1994). Psychometric theory: New York: McGraw-Hill.

[38] Paswan, A. K., Spears, N., \& Ganesh, G. (2007). The effects of obtaining one's preferred service brand on consumer satisfaction and brand loyalty. Journal of Services Marketing.
[39] Podsakoff, P. M., MacKenzie, S. B., Lee, J.-Y., \& Podsakoff, N. P. (2003). Common method biases in behavioral research: a critical review of the literature and recommended remedies. Journal of applied psychology, 88(5), 879.

[40] Popp, B., \& Woratschek, H. (2017). Consumers' relationships with brands and brand communities-The multifaceted roles of identification and satisfaction. Journal of Retailing and Consumer Services, 35, 46-56.

[41] Price, L. L., Arnould, E. J., \& Deibler, S. L. (1995). Consumers' emotional responses to service encounters. International Jorunal of Service Industry Management, 6(3), 34-63.

[42] Raza, A., Saeed, A., Iqbal, M. K., Saeed, U., Sadiq, I., \& Faraz, N. A. (2020). Linking corporate social responsibility to customer loyalty through co-creation and customer company identification: Exploring sequential mediation mechanism. Sustainability, 12(6), 2525.

[43] Ryu, K., \& Han, H. (2010). Influence of the quality of food, service, and physical environment on customer satisfaction and behavioral intention in quick-casual restaurants: Moderating role of perceived price. Journal of Hospitality \& Tourism Research, 34(3), 310-329.

[44] So, K. K. F., King, C., Sparks, B. A., \& Wang, Y. (2013). The influence of customer brand identification on hotel brand evaluation and loyalty development. International Journal of Hospitality Management, 34, 3141.

[45] Söderlund, M. (2017). Employee display of burnout in the service encounter and its impact on customer satisfaction. Journal of Retailing and Consumer Services, 37, 168-176.

[46] Solomon, M. R., Surprenant, C., Czepiel, J. A., \& Gutman, E. G. (1985). A role theory perspective on dyadic interactions: the service encounter. Journal of marketing, 49(1), 99-111.

[47] Stokburger-Sauer, N., Ratneshwar, S., \& Sen, S. (2012). Drivers of consumer-brand identification. International journal of research in marketing, 29(4), 406-418

[48] Su, L., Swanson, S. R., Chinchanachokchai, S., Hsu, M. K., \& Chen, X. (2016). Reputation and intentions: The role of satisfaction, identification, and commitment. Journal of Business Research, 69(9), 3261-3269.

[49] Underwood, R., Bond, E., \& Baer, R. (2001). Building service brands via social identity: Lessons from the sports marketplace. Journal of Marketing Theory and Practice, 9(1), 1-13

[50] Wakefield, \& Baker, J. (1998). Excitement at the mall: determinants and effects on shopping response. Journal of Retailing, 74(4), 515-539.

[51] Walsh, G., Evanschitzky, H., \& Wunderlich, M. (2008). Identification and analysis of moderator variables. European Journal of Marketing.

[52] Wolter, J. S., Bock, D., Smith, J. S., \& Cronin Jr, J. J. (2017). Creating ultimate customer loyalty through loyalty conviction and customercompany identification. Journal of Retailing, 93(4), 458-476.

[53] Wolter, J. S., \& Cronin, J. J. (2016). Re-conceptualizing cognitive and affective customer-company identification: the role of self-motives and different customer-based outcomes. Journal of the Academy of marketing Science, 44(3), 397-413.

[54] Wu, C. H.-J. (2007). The impact of customer-to-customer interaction and customer homogeneity on customer satisfaction in tourism service- the service encounter prospective. Tourism Management, 28(6), 1518-1528.

[55] Wu, C. H.-J., \& Liang, R.-D. (2009). Effect of experiental value on customer satisfaction with service encounters in luxury-hotel restaurants. International Journal of Hospitality Management, 28, 586-593.

[56] Yang, A. J.-F., Chen, Y. J., \& Huang, Y.-C. (2017). Enhancing customer loyalty in tourism services: the role of customer-company identification and customer participation. Asia Pacific Journal of Tourism Research, 22(7), 735-746

[57] Zeithaml, V. A., Berry, L. L., \& Parasuraman, A. (1996). The behavioral consequences of service quality. Journal of Marketing, 60, 31-46. 